\title{
KARAKTERISTIK DAN BEBERAPA KANDUNGAN ZAT GIZI PADA LIMA SAMPEL MADU YANG BEREDAR DI SUPERMARKET
}

\author{
The Characteristic and Nutrient Content of Five Honey Samples Dispersed in Supermarket
}

\author{
Retno Mardhiati ${ }^{1}, 2$, Sri Anna Marliyati ${ }^{2}$, Drajat Martianto ${ }^{2}$, Siti Madanijah ${ }^{2}$, I Wayan T Wibawan ${ }^{3}$ \\ IUniversitas Muhammadiyah Prof. Dr. Hamka, Jl. Limau II, Kebayoran Baru, Jakarta Selatan, 12130 \\ 2Departemen Gizi Masyarakat, Fakultas Ekologi Manusia, Universitas IPB, Jl. Dramaga, Kab. Bogor, 16680 \\ 3Departemen IImu Penyakit Hewan dan Kesmasvet, FKH, Universitas IPB, Jl. Dramaga, Kab. Bogor, 16680 \\ E-mail: retno_ma@uhamka.ac.id
}

\section{ABSTRACT}

Honey is one of the herbal supplements for increasing body health. The nutrient content in honey products can be reduced due to its processing, packing, storage, and industrial process. This study aimed to analyze the characteristic of honey and some of its nutrient contents of 5 honey samples that disperse among the society. This study was conducted from March to September 2019 in the Ministry of Industry Centre for Agro-based Industry Laboratory, Bogor, East Java. Honey samples were obtained from some wholesale supermarkets around the Jakarta area. Total carbohydrate and energy testings were using IK 5.4.5 method. Water content, diastase enzyme activity, hydroxymethylfurfural (HMF) content, and acidity tests were using the Indonesian National Standard (SNI) procedure 3545 2013. HPLC method was used to test sucrose, glucose, and fructose, while AOAC 999.11 (9.1.09.2005 method was used to test $\mathrm{Cu}, \mathrm{Zn}$, and Fe content. Total carotenoid and flavonoid content were determined using spectrophotometry method. The result revealed the characteristic of honey samples in this study, including the range of $\mathrm{pH}$ (3.56-4.16), water (17-22.9\%), ashes (0,07-0,59), acidity (7.76-38.3 ml N NaOH 1/kg) and HMF (122-812 mg/kg) content as well as diastase enzyme activity (1.11-17.2 DN). Fructose, glucose, sucrose and reducing sugar content showed were, respectively, 21.5-39.3 gr/100 gr, 25.2-31.4 gr/100 gr, 0.5-1.75 gr/100 gr, and 58.4-71.2\%. Honey samples contained $309-334 \mathrm{kal} / 100 \mathrm{gr}$ of energy, $76.8-81.9 \%$ of carbohydrate, $0.03-0.39 \%$, of protein and $0.10-0.65 \%$ of fat. Moreover, their mineral contents observed were $0.03-0.66 \mathrm{mg} / \mathrm{kg}$ of $\mathrm{Cu}, 0.09-3.13$ $\mathrm{mg} / \mathrm{kg}$ of $\mathrm{Zn}$, and $1.59-20.1 \mathrm{mg} / \mathrm{kg}$ of Fe. Finally, total flavonoid and carotenoid of honey samples were, respectively, $0.02-0.07 \%(\mathrm{~b} / \mathrm{b})$ and $0.05-0.64 \mathrm{mg} / \mathrm{kg}$.

Keywords: fe, flavonoid, fructose, honey

\section{ABSTRAK}

Madu merupakan salah satu suplemen herba untuk meningkatkan kesehatan tubuh. Kandungan zat gizi dalam produk madu dapat menurun dikarenakan proses pengolahan, pengemasan, dan penyimpanan serta perindustrian. Penelitian ini bertujuan menganalisis karakteristik madu dan beberapa kandungan zat gizi pada 5 sampel madu yang beredar di masyarakat. Penelitian dilakukan pada bulan Maret-September 2019 di Laboratorium Balai Besar Industri Agro Kementerian Perindustrian Bogor Jawa Barat. Metode pengujian total karbohidrat dan energi menggunakan metode IK 5.4.5. Pengujian kadar air, aktivitas enzim diastase, hidroksimetil furfural serta keasaman menggunakan prosedur SNI 3545 2013. Metode HPLC digunakan untuk menguji sukrosa, glukosa, dan fruktosa, sementara metode AOAC 999.11 (9.1.09.2005) digunakan untuk menguji kadar mineral $\mathrm{Cu}, \mathrm{Zn}$, dan Fe dengan metode AOAC. Pengujian total karotenoid dan total flavonoid menggunakan metode spektrofotometer. Hasil memperlihatkan karakteristik sampel madu pada penelitian ini, termasuk rentang pH berkisar (3,56-4,16), kadar air (17-22,9\%), kadar abu 0,070,59, keasaman $(7,76-38,3 \mathrm{ml} \mathrm{N} \mathrm{NAOH} \mathrm{1/kg),} \mathrm{dan} \mathrm{kadar} \mathrm{HMF} \mathrm{(122-812} \mathrm{mg/kg),} \mathrm{serta} \mathrm{aktivitas} \mathrm{enzim} \mathrm{diastase}$ 1,11-17,2 DN. Kandungan fruktosa, glukosa, sukrosa dan kadar gula pereduksi, secara berurutan, berkisar 21,5-39,3 gr/100 gr, 25,2-31,4 gr/100 gr, 0,5-1,75 gr/100 gr, dan 58,4-71,2\%. Sampel madu pada penelitian ini, memiliki kandungan energi berkisar 309-334 kal/100 gr, karbohidrat 76,8-81,9\%, protein 0,03-0,39\%, dan lemak $0,10-0,65 \%$. Kandungan mineral yang teramati yaitu Cu berkisar $0,03-0,66 \mathrm{mg} / \mathrm{kg}$, Zn berkisar $0,09-3,13 \mathrm{mg} / \mathrm{kg}$, dan Fe berkisar 1,59-20,1 mg/kg. Terakhir, total flavonoid dan total karotenoid dalam sampel madu, masing-masing berkisar 0,02-0,07 \%(b/b) dan 0,05-0,64 mg/kg.

Kata kunci: madu, flavonoid, fe, fruktosa

Doi: $10.36457 /$ gizindo.v\%vi\%i.507

www.persagi.org/ejournal/index.php/Gizi_Indon 


\section{PENDAHULUAN}

$\mathrm{P}$ eran Madu dalam kesehatan sudah banyak dibuktikan secara ilmiah. Kebiasaan konsumsi madu juga berkaitan dengan penurunan beberapa risiko penyakit terutama infeksi organ pencernaan. Madu merupakan pemanis alami dan makanan bergizi. ${ }^{1}$ Madu digunakan sebagai pengobatan tradisional di masyarakat. Madu bersifat sebagai senyawa yang dapat mencegah dan mengobati beberapa penyakit yang disebabkan oleh bakteri maupun virus. ${ }^{2}$ Madu memiliki kemampuan terapetik sebagai antiinflamasi, antimikroba, kesehatan gastro, kesehatan saraf, anti kanker, antidiabetik, dan sebagai antioksidan. ${ }^{3}$ Madu juga memiliki kemampuan efek hepatoprotektif dan nefroprotektif, yang diduga berasal dari kandungan antioksidan. ${ }^{4}$ Madu memiliki kemampuan antimkikroba baik pada bakteri positif maupun bakteri negatif. Kemampuan madu ini dikarenakan adanya senyawa polifenol, hidrogen peroksida, metilglioksal. Namun senyawa -senyawa dalam madu sangat bervariasi tergantung pada jenis lebah, wilayah, jenis tanaman yang sering dikunjungi oleh lebah, dan sumber nektar. ${ }^{5}$ Madu juga memiliki kemampuan imunomodulator 2,6,7,9 Madu juga menurunkan kejadian komplikasi gastrointestinal secara signifikan. ${ }^{8} \quad$ Madu memiliki kemampuan melindungi tubuh dari efek radikal bebas dan ROS yang merusak sel. Madu juga memiliki kemampuan efek hepatoprotektif dan nefroprotektif, yang diduga berasal dari kandungan antioksidan. ${ }^{10,11}$

Produksi madu berbagai merek sudah tersedia, baik di pasar tradisional maupun supermarket, sehingga masyarakat dapat dengan mudah memilih berbagai macam jenis madu. Madu terdiri berbagai macam jenis, yang dibedakan dari warna, rasa, kekentalan, dan asal pohon sebagai sumber nektar atau sumber daerah. Kualitas madu di Indonesia diatur menurut SNI standar madu tahun 2013. Madu yang berkualitas baik memiliki aktivitas enzim diastase min 3 DN, kandungan maksimal hidroksimetilfurfural $50 \mathrm{mg} / \mathrm{kg}$, kadar air maksimal $22 \% \mathrm{~b} / \mathrm{b}$, kandungan abu maksimal $0.5 \%$, kandungan sukrosa maksimal $5 \% \mathrm{~b} / \mathrm{b}$, keasaman maksimal $50 \mathrm{ml} \mathrm{NAOH} 1 \mathrm{~N} / \mathrm{kg}$ dan batas cemaran logam $\mathrm{Pb}$ maksimal $1 \mathrm{mg} / \mathrm{kg}$, cemaran logam $\mathrm{Cu}$ maksimal $5 \mathrm{mg} / \mathrm{kg}$, dan cemaran arsen maksimal $0.5 \mathrm{mg} / \mathrm{kg}$.

Kandungan madu yang utama adalah karbohidrat, yang lebih dari 80 persen. Adanya beberapa kandungan vitamin dan mineral serta beberapa senyawa fenolik, menjadikan madu sebagai makanan fungsional yang baik untuk dikonsumsi masyarakat. ${ }^{12,13}$ Madu juga diduga mengandung prebiotik yakni inggredients suatu bahan makanan yang dapat memberikan pengaruh menguntungkan bagi kesehatan karena dapat menstimulus pertumbuhan dan aktivitas berbagai mikroba baik di dalam saluran pencernaan. Prebiotik yang berpontensi dalam madu adalah karbohidrat dalam bentuk oligosakarida. Madu mengandung beberapa vitamin namun kandungan vitamin hanya terdeteksi dalam jumlah yang kecil. 12,13,14 Madu ditemukan mengandung beberapa vitamin seperti terutama riboflavin, niasin, pantotenat asam, piridoksin, folat, dan vitamin C. Madu juga mengandung beberapa enzim seperti katalase, superoksida dismutase, glutation tereduksi. Kandungan flavonoid seperti apigenin, pinocembrin, kaempferol, quercetin, galangin, chrysin dan hesperetin, dan asam fenolik (seperti asam ellagik, caffeik, pkoumarik, dan ferulik). ${ }^{2}$ Asal madu mempengaruhi jumlah senyawa bioaktif dan mampu berdampak pada sifat antimikroba madu. ${ }^{5}$ Antioksidan yang terkandung dalam madu berupa antioksidan enzimatik (diastase, invertase, glukosa oksidase) dan antioksidan non enzimatik (asam fenolik, flavonoid, asam amoni, asam organik). Kadar antioksidan dalam madu dipengaruhi oleh sumber, asal geografis, kondisi iklim, pemrosesan, penyimpanan, dan penanganan produk madu. ${ }^{1}$ Madu Indonesia ditemukan memiliki keragaman kandungan gizi. Keragaman kandungan total flavonoid pada madu berdasarkan asal pohon ditemukan Bunga Rambutan $3,80 \pm 0,66 \mathrm{mg}$ quercetin/100g, Bunga Kelengkeng 4,94 $\pm 0,66$ $\mathrm{mg}$ quercetin/100g, Bunga Kopi 23,94 $\pm 1,14$ $\mathrm{mg}$ quercetin/100g, Bunga Randu 12,92 $\pm 2,87$ $\mathrm{mg}$ quercetin/100g, Bunga Kaliandra 33,46 \pm $2,28 \mathrm{mg}$ quercetin/100g. ${ }^{15}$ Perbedaan kandungan biologis madu juga ditemukan antar daerah, dimana madu hutan Sumbawa dari Pulau Moyo memiliki senyawa fenol dan aktivitas antioksidan yang lebih tinggi daripada madu dari Lape, Tepal dan Punik. ${ }^{16}$ Berdasarkan uraian diatas, tujuan penelitian ini 
adalah menganalisis karakteristik 5 sampel madu yang beredar di supermarket di DKI Jakarta dan kandungan beberapa zat gizinya.

\section{METODE PENELITIAN}

Penelitian ini merupakan penelitian deskriptif tentang karakteristik madu dan kandungan zat gizinya. Penelitian dilakukan di laboratorium Balai Besar Industri Agrobisnis, Balai Penelitian dan Pengembangan Industri, Kementerian Perindustrian Republik Indonesia, Bogor. Penelitian juga dilakukan di Laboratorium Pusat Studi Biofarmaka LPPM IPB Bogor. Waktu penelitian dilakukan pada bulan Desember 2018 sampai Maret 2019. Penelitian menggunakan 5 sampel madu yang beredar di supermarket wilayah DKI Jakarta. Analisis sifat fisikokimia madu meliputi ph, kadar air, kadar abu, keasaman, aktifitas enzim diastase, dan hidroksimetilfurfural (HMF). Analisis kandungan gula meliputi fruktosa, glukosa, sukrosa, dan gula pereduksi. Analisis kandungan zat gizi makro meliputi energi, karbohidrat, protein dan lemak. Analisis kandungan mineral meliputi tembaga, seng, besi, selenium. Analisis kandungan zat bioaktif meliputi total flavonoid dan total karotenoid.

Bahan sampel EVOO diperoleh dari supermarket besar di wilayah DKI Jakarta. Jumlah sampel 7 merek EVOO yang memiliki standar keaslian EVOO. Hanya 1 sampel tiap merek EVOO yang diteliti dalam penelitian ini. Bahan kimia yang digunakan dalam penelitian ini yaitu reagen wijs, Kalium iodida $10 \%$, karbon tetraklorida, larutan indikator pati segar, kalium dikromat, natrium tisulfat, $\mathrm{HCL} 25 \%$, aquades, etanol 95\%, indikator fenolftalein (pp) $1 \%$, Larutan standardisasi kalium hidroksida $(\mathrm{KOH})$
$0,1 \mathrm{~N}$ atau larutan natrium hidroksida $(\mathrm{NaOH})$ $0,1 \mathrm{~N}$, larutan $\mathrm{AlCl} 32 \%$, dan kalium asetat 120 $\mathrm{mM}$,

Alat yang digunakan dalam penelitian ini yaitu oven, desikator, pinggan aluminium, labu erlenmeyer $250 \mathrm{ml}$, labu takar $1000 \mathrm{ml}$, pipet ukuran $2-5 \mathrm{ml}, 20 \mathrm{ml}, 25 \mathrm{ml}, 50 \mathrm{ml}$, pelat magnetik pengaduk, neraca analitik, gelas piala $50 \mathrm{ml}$, pengukur waktu, kertas saring, buret 10 $\mathrm{ml}$, cawan porselen, tanur listrik, alat HPLC, alat kromatografi gas (HP 5890 series II) dan alat spektrofotometer (Shimadzu AA-7000).

Metode Uji zat gizi makro menggunakan teknik yang distandarkan SNI 01-2891-1992, sedangkan pengujian karbohidrat dan energi menggunakan metode IK 5.4.5. Pengujian kadar air, aktivitas enzim diastase, hidroksimetil furfural serta keasaman menggunakan prosedur SNI 3545 2013. Pengujian sukrosa, glukosa, fruktosa menggunakan metode HPLC. Pengujian kadar mineral $\mathrm{Cu}, \mathrm{Zn}$, dan Fe dengan metode AOAC 999.11 (9.1.09.2005). Pengujian total karotenoid dan total flavonoid menggunakan metode spektrofotometer. Sampel madu yang diperiksa adalah sampel madu dari produk madu yang ada di supermarket. Analisis data yang digunakan adalah analisis deskriptif.

\section{HASIL}

Penelitian ini menggambarkan karakteristik madu meliputi $\mathrm{pH}$, kadar air, abu, keasaman, aktivitas enzim diastase, dan HMF. Penelitian ini juga menggambarkan kandungan fruktosa, glukosa, sukrosa, dan kandungan zat gizi makro. Selain itu, kandungan mineral ( $\mathrm{Cu}, \mathrm{Zn}$, $\mathrm{Fe}, \mathrm{Se}$ ), dan kandungan total flavonoid dan total karotenoid juga akan ditampilkan dalam penelitian ini.

Tabel 1

Karakteristik 5 Sampel Madu

\begin{tabular}{lcccccc}
\hline Kriteria & Sampel & Sampel & Sampel & Sampel & Sampel & $\begin{array}{c}\text { Rerata } \pm \\
\text { Standar } \\
\text { Deviasi }\end{array}$ \\
\hline pH & 1 & 2 & 3 & 4 & 5 & $4,92 \pm 0,25$ \\
Kadar air (\% b/b) & 3,56 & 3,78 & 4,08 & 4,04 & 4,16 & $3,22 \pm 2,37$ \\
Abu (\% b/b) & 17 & 22,9 & 19,7 & 19,2 & 17,3 & $19,22 \pm 0,370$ \\
Keasaman (ml N NAOH 1/kg) & 0,32 & 0,07 & 0,59 & 0,37 & 0,35 & $0,34 \pm 0,18$ \\
Aktifitas enzim diastase (DN) & 21,1 & 7,76 & 17,9 & 16,4 & 38,3 & $20,29 \pm 11,2$ \\
HMF (mg/kg) & 5,12 & 1,11 & 17,2 & 10,2 & 10,2 & $38,77 \pm 6,07$ \\
\hline
\end{tabular}


Dalam penelitian ini pH berkisar 3,56-4.16, kadar air 17-22,9 \% b/b, kadar abu berkisar 0,07-0,59 \% b/b, keasaman 7,76-38,3 ml N $\mathrm{NAOH} 1 / \mathrm{kg}$, aktivitas enzim diastase 1,11-17,2 DN, HMF berkisar $122-812 \mathrm{mg} / \mathrm{kg}$. Rerata $\mathrm{pH}$ 3,92 , dengan $\mathrm{pH}$ tertinggi pada sampel 5 . Rerata kadar air 19,22 \%, dengan kadar air tertinggi pada sampel ke 2. Rerata kadar abu $0,34 \% \mathrm{~b} / \mathrm{b}$ dengan kadar abu tertinggi 0,59 . Rerata keasaman $20,29 \mathrm{ml} \mathrm{N} \mathrm{NAOH} 1 / \mathrm{kg}$, dengan keasaman tertinggi pada sampel 5 . Rerata aktivitas enzim diastase $38,77 \mathrm{DN}$, dengan sampel tertinggi pada sampel ke 3 . Rerata kadar HMF 292,4 mg/kg, dengan sampel tertinggi pada sampel ke 2. (Tabel 1)

Kandungan energi berkisar 309-334 kal/ $100 \mathrm{~g}$, dengan rerata kandungan energi 322,8 kal/100g dan paling tinggi kandungan energi pada sampel ke 1 . Kandungan karbohidrat berkisar 76,8-81,9\%, dengan rerata kandungan karbohidrat $80,1 \%$ dan paling tinggi kandungan karbohidrat pada sampel 1. Kandungan protein berkisar 0,03-0,39\%, dengan rerata kandungan protein $0,134 \%$ dan kandungan protein tertinggi pada sampel 5. Kandungan lemak berkisar 0,1$0,65 \%$, dengan rerata kandungan lemak $0,23 \%$ dan tertinggi pada sampel 1. (Tabel 2)

Rerata fruktosa $31,38 \mathrm{~g} / 100 \mathrm{~g}$ dengan kisaran 21,5-39,3g/100g. Rerata glukosa 27,72 $\mathrm{g} / 100 \mathrm{~g}$ dengan kisaran 25,2-31,4 g/100g. Rerata sukrosa 0,39 $\mathrm{g} / 100 \mathrm{~g}$. Rerata gula pereduksi $64,2 \%$ dengan kisaran 58,4-71,2 $\mathrm{g} / 100 \mathrm{~g}$. Sampel ke 1 memiliki kandungan fruktosa, glukosa, dan sukrosa tertinggi. Gula pereduksi tertinggi ada pada sampel ke 2 . (Tabel 3)

Tabel 2

Kandungan Zat Gizi Makro pada 5 Sampel Madu

\begin{tabular}{lcccccc}
\hline Zat Gizi Makro & $\begin{array}{c}\text { Sampel } \\
1\end{array}$ & $\begin{array}{c}\text { Sampel } \\
2\end{array}$ & $\begin{array}{c}\text { Sampel } \\
3\end{array}$ & $\begin{array}{c}\text { Sampel } \\
4\end{array}$ & $\begin{array}{c}\text { Sampel } \\
5\end{array}$ & $\begin{array}{c}\text { Rerata } \pm \\
\text { Standar } \\
\text { Deviasi }\end{array}$ \\
\hline Energi (kal/ $100 \mathrm{~g})$ & 334 & 309 & 319 & 322 & 330 & $322,8 \pm 9,78$ \\
Karbohidrat (\%) & 81,9 & 76,8 & 79,5 & 80,3 & 81,8 & $80,1 \pm 2,10$ \\
Protein (\%) & 0,13 & 0,05 & 0,07 & 0,03 & 0,39 & $0,134 \pm 0,15$ \\
Lemak (\%) & 0,65 & 0,15 & 0,11 & 0,10 & 0,12 & $0,23 \pm 0,24$ \\
\hline
\end{tabular}

Tabel 3

Kandungan Fruktosa, Glukosa, Sukrosa, dan Gula Pereduksi pada 5 Sampel Madu

\begin{tabular}{lcccccc}
\hline Kandungan & $\begin{array}{c}\text { Sampel } \\
1\end{array}$ & $\begin{array}{c}\text { Sampel } \\
2\end{array}$ & $\begin{array}{c}\text { Sampel } \\
3\end{array}$ & $\begin{array}{c}\text { Sampel } \\
4\end{array}$ & $\begin{array}{c}\text { Sampel } \\
5\end{array}$ & $\begin{array}{c}\text { Rerata } \pm \\
\text { Standar } \\
\text { Deviasi }\end{array}$ \\
\hline Fruktosa $(\mathrm{g} / 100 \mathrm{~g})$ & 39,3 & 37,7 & 21,5 & 22,4 & 36 & $31,38 \pm 8,69$ \\
Glukosa $(\mathrm{g} / 100 \mathrm{~g})$ & 31,4 & 29,0 & 25,2 & 27,6 & 25,4 & $27,72 \pm 2,59$ \\
Sukrosa $(\mathrm{g} / 100 \mathrm{~g})$ & 1,75 & $<0,50$ & $<0,50$ & $<0,50$ & $<0,50$ & $0,39 \pm 0,76$ \\
Gula pereduksi $(\%)$ & 71 & 71,2 & 58,4 & 60,6 & 59,8 & $64,2 \pm 6,35$ \\
\hline
\end{tabular}

Tabel 4

Kandungan Mineral (Cu, Zn, Fe, Se) pada 5 Sampel Madu

\begin{tabular}{|c|c|c|c|c|c|c|}
\hline Mineral & $\begin{array}{l}\text { Sampel } \\
1\end{array}$ & $\begin{array}{l}\text { Sampel } \\
2\end{array}$ & $\begin{array}{c}\text { Sampel } \\
3\end{array}$ & $\begin{array}{l}\text { Sampel } \\
4\end{array}$ & $\begin{array}{l}\text { Sampel } \\
5\end{array}$ & $\begin{array}{c}\text { Rerata } \pm \\
\text { Standar } \\
\text { Deviasi }\end{array}$ \\
\hline $\begin{array}{l}\text { Tembaga } \\
\mathrm{mg} / \mathrm{kg}\end{array}$ & 0,03 & 0,03 & 0,04 & 0,05 & 0,66 & $0,16 \pm 0,28$ \\
\hline Seng $(Z n)$ mg/kg & 0,79 & 0,09 & 0,56 & 0,86 & 3,13 & $1,1 \pm 1,2$ \\
\hline Besi (Fe) mg/kg & 3,45 & 1,59 & 14,3 & 20,1 & 3,82 & $8,65 \pm 8,11$ \\
\hline Selenium (Se) mg/kg & $<0,002$ & $<0,002$ & $<0,002$ & $<0,002$ & $<0,002$ & - \\
\hline
\end{tabular}


Tabel 5

Kandungan Total Flavonoid dan Total Karotenoid pada 5 Sampel Madu

\begin{tabular}{lcccccc}
\hline Senyawa & $\begin{array}{c}\text { Sampel } \\
1\end{array}$ & $\begin{array}{c}\text { Sampel } \\
2\end{array}$ & $\begin{array}{c}\text { Sampel } \\
3\end{array}$ & $\begin{array}{c}\text { Sampel } \\
4\end{array}$ & $\begin{array}{c}\text { Sampel } \\
5\end{array}$ & $\begin{array}{c}\text { Rerata } \pm \\
\text { Standar } \\
\text { Deviasi }\end{array}$ \\
\hline Total Flavanoid, \%(b/b) & 0,04 & 0,02 & 0,04 & 0,07 & 0,05 & $0,04 \pm 0,02$ \\
Total Karotenoid, $\mathrm{mg} / \mathrm{kg}$ & $<0,05$ & $<0,05$ & $<0,05$ & 0,64 & $<0,05$ & - \\
\hline
\end{tabular}

Kandungan beberapa mineral ditemukan pada 5 sampel madu yakni $\mathrm{Cu}, \mathrm{Zn}, \mathrm{Fe}$, dan $\mathrm{Se}$. Rerata kandungan $\mathrm{Cu} 0,16 \mathrm{mg} / \mathrm{kg}$ dengan kisaran 0,03-0,66 mg/kg. Rerata kandungan $\mathrm{Zn}$ $1,1 \mathrm{mg} / \mathrm{kg}$ dengan kisaran $0,09-3,13 \mathrm{mg} / \mathrm{kg}$. Rerata kandungan $\mathrm{Fe} 8,65 \mathrm{mg} / \mathrm{kg}$ dengan kisaran 1,59-20,1 mg/kg. Sampel ke 5 memiliki kandungan $\mathrm{Cu}$ dan $\mathrm{Zn}$ tertinggi diantara sampel yang lain. Kandungan Fe tertinggi pada sampel ke 4. Semua sampel memiliki kandungan Se, hanya kadarnya sangat kecil yakni kurang dari 0,002. (Tabel 4)

Kandungan total flavonoid berkisar 0,02 $0,07 \% \mathrm{~b} / \mathrm{b}$ dengan rerata $0,04 \% \mathrm{~b} / \mathrm{b}$. Sampel ke 4 memiliki kandungan total flavonoid tertinggi. Kandungan total karotenoid tertinggi juga pada sampel 4, sedangkan sampel lainnya sangat kecil, dengan nilai dibawah 0,05. (Tabel 5)

\section{BAHASAN}

Besaran pH menunjukkan tingkat keasaman madu. Dalam penelitian ini, $\mathrm{pH}$ paling rendah 3,56 dan tertinggi 4,08. Semakin rendah $\mathrm{pH}$, maka semakin tinggi tingat keasamannya. Beberapa kandungan asam organik dalam madu menentukan besaran pHnya seperti asam sitrat, asam laktat, asam butirat, asam oksalat. Faktor lain yang juga menentukan $\mathrm{pH}$ yaitu proses pengolahan, tekstur, stabilitas, dan umur simpan madu. ${ }^{17} \mathrm{pH}$ rendah juga mencegah pembusukan. ${ }^{5}$ Ketika $\mathrm{pH}$ rendah, jamur dan ragi ditemukan pada madu asal Turki. ${ }^{17}$. Beberapa madu menunjukkan $\mathrm{pH}$ yang hampir sama dengan penelitian ini. Madu di India dan Pakistan memiliki pH 3,2-4,5 dan madu kemasan lebih rendah daripada madu mentah. ${ }^{2}$ Kisaran $\mathrm{pH}$ madu di luar wilayah Indonesia tidak berbeda jauh dengan madu Indonesia. Madu asal Turki memiliki pH 3,33-5,54. Madu asal Maroko memiliki pH 3,52-5,13.18 Madu dari pohon Lingonberry di hutan Finlandia memiliki $\mathrm{pH}$ 4,5 dan pohon Meri 4,9.19 Madu Tualang dari Malaysia memiliki pH 3,55-4 dan madu Manuka dari Australia 3,2-4,21. Madu Tualang merupakan madu yang berasal dari nektar multiflora, sedangkan madu Manuka merupakan madu dari nektar monofloral. ${ }^{20,21}$ Madu hutan asal Kabupaten Bima memiliki pH 4,2.22 Madu dari Sumatera Barat berkisar 3,42-6,01.23

Dalam penelitian lain, ditemukan tingkat keasaman, pada madu kemasan $(0,2-0,8)$ dan madu mentah $(0,8-1,5){ }^{2}$ Hal ini juga didukung oleh data madu kemasan memiliki $\mathrm{pH}$ lebih rendah daripada $\mathrm{pH}$ madu mentah. Keasaman pada madu-madu yang berasal dari Sulawesi Selatan yakni madu Maros $(45,43 \mathrm{ml} \mathrm{NaOH} / \mathrm{kg})$, madu Pangkep $(83,06 \mathrm{ml} \mathrm{NaOH} / \mathrm{kg})$, dan madu Gowa $(51,5 \mathrm{ml} \mathrm{NaOH} / \mathrm{kg}){ }^{24}$

Kadar air hasil penelitian ini menunjukkan masih dibawah standar kecuali sampel 2. Kadar air pada madu dipengaruhi oleh iklim dan penanganan paska panen. ${ }^{25}$ Madu di India dan Pakistan memiliki kadar kadar air $17 \%{ }^{2}$ dimana kadar air berperan penting pada kemampuan madu sebagai antimikroba. Kadar air pada madu kemasan sama dengan madu mentah. ${ }^{14}$ Kadar air madu di Indonesia, yang berasal dari pohon kaliandra $(26,52 \%)$, kelengkeng $(22,67 \%)$, rambutan $(18,95 \%)$, dan madu randu (20,77\%). ${ }^{26}$ Madu pohon karet di Bangka Tengah memiliki kadar air 24,25 \%. ${ }^{27}$ Kadar air madu Tualang dan madu Manoka sangat kecil yakni $0,19 \%$ dan 0,093 \%.28 Kadar air pada madu-madu yang berasal dari Sulawesi Selatan yakni madu Maros (19,19 \% b/b), madu Pangkep $(22,29 \%$ b/b), dan madu Gowa $(24,92$ $\%$ b/b). ${ }^{24}$

Kadar abu pada sampel madu penelitian ini berkisar 0,07-0,59 \% b/b. Kadar abu pada madu-madu yang berasal dari Sulawesi Selatan yakni madu Maros $(0,045 \% \mathrm{~b} / \mathrm{b})$, madu Pangkep $(0,35 \% \mathrm{~b} / \mathrm{b})$, dan madu Gowa $(0,52 \%$ b/b). ${ }^{24}$ Kadar abu menunjukkan Madu di India dan Pakistan memiliki kadar abu berkisar 0,2 
\%.2 Enzim utama pada madu yakni enzim diastase dan invertase, yang menjadi penanda kualitas madu dan kesegaran madu..$^{28}$

HMF merupakan senyawa organik yang terbentuk oleh dehidrasi gula sebagai tanda kerusakan madu oleh pemanasan atau menambahan gula, serta penyimpanan. Hal ini mungkin disebabkan oleh indikator HMF yang sangat tinggi. Kadar HMF hasil penelitian ini menunjukkan semua sampel masih dibawah standar. Tingginya kadar HMF pada madu kemasan dipengaruhi banyak faktor termasuk asal madu, cara memanen madu, pengemasan madu, dan penyimpanan madu. Madu pohon karet di Bangka Tengah memiliki kadar HMF 0 $\mathrm{mg} / \mathrm{kg}^{27}$ Kadar HMF pada madu-madu yang berasal dari Sulawesi Selatan yakni madu Maros (2,99 $\mathrm{mg} / \mathrm{kg})$, madu Pangkep (2,84 $\mathrm{mg} / \mathrm{kg})$, dan madu Gowa $(3,175 \mathrm{mg} / \mathrm{kg}) .{ }^{24}$ Kadar HMF madu Tualang dan madu Manoka yakni $46,17 \mathrm{mg} / \mathrm{kg}$ dan $40 \mathrm{mg} / \mathrm{kg}^{20}$

Jenis karbohidrat utama dalam madu adalah glukosa dan fruktosa. ${ }^{5,26,29}$ Kandungan glukosa dan fruktosa ini mempengaruhi sifat higroskopis madu, dimana sifat hidroskopis juga dipengaruhi oleh sumber madunya. Rasio antara fruktosa/ glukosa dan glukosa/ kadar air merupakan parameter yang digunakan untuk memprediksi kristalisasi pada madu. ${ }^{26}$ Hasil penelitian ini menunjukkan kandungan fruktosa berkisar 21,5-39,3 g/100 g, mendekati hasil yang sama dengan kandungan madu hasil penelitian-penelitian yang lain. Kandungan gula pereduksi pada madu-madu yang berasal dari Sulawesi Selatan yakni madu Maros (69 \%b/b), madu Pangkep $(68,5 \% \mathrm{~b} / \mathrm{b})$, dan madu Gowa $(53,5 \% \mathrm{~b} / \mathrm{b}){ }^{24}$ Madu di India dan Pakistan mengandung fruktosa $32,56-38,2 \%$, glukosa 28,54-31,3 \%, gula lainnya $9,8 \%{ }^{2}$ Temuan pada penelitian lainnya, kandungan sukrosa ada $4,6 \%$, glukosa $23,63 \%$, fruktosa $47,98 \%$ pada madu. ${ }^{29}$ Madu Tualang dari Malaysia ditemukan memiliki fruktosa $29,6 \%$, glukosa $30 \%$, sukrosa $0,6 \%$, dan gula pereduksi $67,5 \%$, sedangkan madu Manuka dari Australia kadar fruktosa $40 \%$, glukosa $36,2 \%$, sukrosa $02,8 \%$, dan gula pereduksi $76 \%{ }^{28}$ Madu jenis unifloral dari Finlandia, dari pohon lingonberry memiliki fruktosa 40,3 g/100g, dari pohon Meri 39,2 $\mathrm{g} / 100 \mathrm{~g}$, sedangkan dari multifloral $47,3 \mathrm{~g} / 100 \mathrm{~g}$. Kandungan fruktosa dari madu multifloral lebih tinggi daripada madu unifloral. Kandungan glukosa juga lebih tinggi pada madu multifloral daripada unifloral, dari pohon lingonberry $27,7 \mathrm{~g} / 100 \mathrm{~g}$, pohon Meri $28,2 \mathrm{~g} / 100 \mathrm{~g}$, sedangkan multifloral $47,9 \mathrm{~g} / 100 \mathrm{~g} .{ }^{19}$ Rasa manis pada madu berasal, terutama dari sukrosa. Fruktosa, glukosa, galaktosa, maltose, dan laktosa. Dalam $100 \mathrm{~g}$ madu, ada perbedaan kandungan glukosa antara madu kemasan dan madu mentah. Fruktosa dan glukosa lebih tinggi pada madu kemasan (fruktosa $30-45 \mathrm{~g}$, glukosa 24-40 g) daripada madu mentah (fruktosa 20-40 g, glukosa 19-32 g), sedangkan kandungan sukrosa hampir sama. Monosakarida (fruktosa dan glukosa) merupakan gula madu yang paling penting dan berkontribusi paling banyak memberikan efek kesehatan. Kandungan disakarida dalam madu jumlahnya lebih kecil daripada monosakarida.

Kandungan energi dalam penelitian ini cukup tinggi, dengan nilai berkisar 309-334 $\mathrm{kal} / 100 \mathrm{~g}$. Kandungan karbohidrat pada hasil penemuan penelitian ini masih menunjukkan lebih rendah dibandingkan penelitian yang lain. Kandungan karbohidrat pada madu merupakan kandungan tertinggi. Karbohidrat utama dalah monosakarida berkisar $65-80 \% .{ }^{30}$ Madu menyatakan di India dan Paskistan mengandung protein $0,3 \% .{ }^{2}$ Kandungan protein pada madu $0,62 \%$ dan lipid $0,04 \% .{ }^{19}$ Kandungan total asam amino pada madu kemasan (0,2-0,4 gram) dan madu mentah (0,4$0,7 \mathrm{~g}) .^{28}$ Dalam beberapa penelitian, proline merupakan asam amino primer dalam madu. ${ }^{11}$

Dalam sampel madu penelitian ini, kandungan mineral yang ditemukan hanya $\mathrm{Cu}$, $\mathrm{Zn}, \mathrm{Fe}$, dan Se. Kisaran kadar mineral dalam penelitian ini mendekati kadar yang ditemukan peneliti lain. Ada banyak vitamin dan mineral dalam madu, hanya karena jumlahnya kecil, seringkali tidak terdeteksi dalam pemeriksaan. ${ }^{11}$ Madu ditemukan mengandung kalium sebagai mineral utama, dan kandungan mineral fosfor, kalsium, natrium, magnesium, seng, besi, dan mangan. ${ }^{19}$ Dalam $100 \mathrm{~g}$ madu dari Iran, ditemukan Na 1,6-17 g, B1 0,00-0,01 g, Ca 3-31 g, B2 0,01-0,02 g, K 40-3500 g, B3 0,1-0,2 g, Mg 0,7-13 g, B5 0,02-0,11 g, P 2-15 g, B6 0,01$0,32 \mathrm{~g}$, Se 0,002-0,01 g, B9 0,002-0,01 g, Cu 0,02-0,6 g, C 2,2-2,5 g, Fe 0,03-4 g, Mn 0,02-2 g, Cr 0,01-0,3 g, dan Zn 0,05-2 g. ${ }^{14}$ Kandungan beberapa mineral pada madu Tualang Malaysia yakni potassium $(0,51 \%)$, calsium $(0,18 \%)$, magnesium $(0,11 \%)$, dan sodium $(0,26 \%)$ dan madu Manuka Australia yakni potassium (1\%), 
calsium (1\%), magnesium (1\%), dan sodium $(0,0008 \%){ }^{20}$

Madu memiliki kandungan beberapa senyawa fenol. Penelitian ini menemukan kandungan total flavonoid berkisar 0,02-0,07 \% $\mathrm{b} / \mathrm{b}$ dan kandungan total karotenoid $0,64 \mathrm{mg} / \mathrm{kg}$ pada 1 sampel, sedangkan 4 sampel yang lain dibawah $0,05 \mathrm{mg} / \mathrm{kg}$. Kandungan flavonoid dalam madu manuka diantaranya senyawai flavonol (quercetin, kaempferol, dan pinobanksin), flavon (luteolin, apigenin, dan chrysin), flavanon (naringenin, pinocembrin, dan hesperetin), isoflavon (genistein), dan anthocyanidins, namun terdeteksi dalam jumlah yang kecil. ${ }^{31}$ Madu yang gelap lebih banyak memiliki kandungan flavonoid, asam askorbat dan $\beta$-karoten dibandingkan madu yang cerah. ${ }^{11}$ Warna madu dalam penelitian ini semuanya madu cerah kecuali madu hitam. Sebuah penelitian menemukan kandungan senyawa fenol yang ditemukan di madu Tualang dan madu Manuka yakni benzoic acid, gallic acid, dan syringic acid. Senyawa fenol yang ada di madu Tualang namun tidak ada di madu Manuka yakni p-coumaric acid, Hyacinthin, catechin, kaempferol, caffeic acid, trans-cinnamic acid, naringenin, luteolin. Sebaliknya, senyawa fenol yang ada di madu Manuka namun tidak ada di madu Tualang yakni apigenin, salicylic acid, 3-phenyllactic acid, 3,5-dimethoxy benzoic acid, methyl syringate, desoxyanisoin, pinostrobin chalcone, pinocembrin, tectochrysin, dan chrysin. ${ }^{20}$ Kapasitas antioksidan pada senyawa fenol di madu, berbeda-beda, dipengaruhi jenis madu, asal nektar, dan geografis yang berbeda. Senyawa fenol dalam madu memiliki kapasitas untuk mengurangi radikal bebas dengan cara memodulasi enzim aktivitas antioksidan seperti katalase ${ }^{31}$ Kandungan senyawa phenol yang ditemukan pada madu unifloral (pohon lingonberry dan pohon Meri) di hutan Finlandia antara lain cinnamic acid, vanillic acid, benzoic acid, ferulic acid, galangin, dan methylnaringenin. ${ }^{19}$ Madu monofloral lebih rendah kandungan flavonoidnya dibandingkan madu multifloral. ${ }^{20}$

\section{SIMPULAN DAN SARAN}

\section{Simpulan}

Kandungan total karbohidrat berkisar 76.8$81.9 \%$. Kandungan fruktosa berkisar 21.5-39.3 g/100 g madu. Kandungan glukosa 25.2-31.4 $\mathrm{g} / 100 \mathrm{~g}$. Kandungan sukrosa berkisar 0-1.75 $\mathrm{g} / 100 \mathrm{~g}$. Sampel ke 4 memiliki kandungan total flavonoid dan total karotonoid tertinggi dibandingkan sampel yang lain. Kandungan total flavonoid dan total karotenoid dalam sampel madu, masing-masing berkisar 0.02$0.07 \%(\mathrm{~b} / \mathrm{b})$ dan $0.05-0.64 \mathrm{mg} / \mathrm{kg}$.

\section{Saran}

Hasil penelitian ini dapat digunakan sebagai data dasar untuk penelitian lanjut yang menggunakan madu sebagai bahan intervensi, baik pada manusia maupun pada hewan. Penelitian lanjut dapat dilakukan untuk melihat pengaruh pemberian madu dalam status imun, kesehatan pencernaan atau kesehatan lainnya.

\section{UCAPAN TERIMA KASIH}

Terima kasih penulis sampaikan kepada Lembaga Penelitian dan Pengembangan Universitas Muhammadiyah Prof Hamka atas bantuan dana penelitian yang telah diberikan untuk pemeriksaan kandungan gizi madu.

\section{RUJUKAN}

1. Nayik GA, Shah TR, Muzaffar K, Wani SA, Gull A, Majid I, Bhat FM. Honey: Its History And Religious Significance: A Review. Universal Journal of Pharmacy. 2014; 03(01): 5-8

2. Arawwawala LDAM, Hewageegana HGSP. Health benefits and traditional uses of honey: A review. J Apither. 2017; 2(1): 9-14

3. Rao PV, Krishnan KT, Salleh N, Gan SH. Biological \& therapeutic effects of honey produced by honey bees $\&$ stingless bees: a comparative review. Revista Brasileira de Farmacognosia. 2016; 26: 657-664

4. Scepankova H, Saraiva JA, Estevinho LM. Honey Health Benefits and Uses in Medicine. Handbook Bee products-chemical and biological properties. 2017: 83-96

5. Nolan VC, Harrison J, Cox JAG. Review Dissecting the Antimicrobial Composition of Honey. Antibiotics 2019; 8 (251): 1-16

6. Erejuwa OO, Sulaiman SA, Wahab MS. Review Honey: A Novel Antioxidant. International Journal of Molecules Sciences. 2012; 17:44004423

7. Tonks, J.; Cooper, R.A.; Jones, K.P.; Blair, S.; Parton, J.; Tonks, A. Honey stimulates inflammatory cytokine production from monocytes. Cytokine. 2003; 21: 242-247 
8. Owoyele BV, Adenekan OT, Soladoye AO. Effects of Honey on Inflammation and Nitric Oxide Production in Wistar Rats. 2011; 9(4): 447-452

9. Ebrahimi $M$, Allahyarib $A$, Ebrahimic $M$, Toroghid HM, , Hosseinid G, Karimie M, Rezaieane A, Kazemi MR. Effects of Dietary Honey \& Ardeh Combination on Chemotherapy Induced Gastrointestinal \& Infectious Complications in Patients with Acute Myeloid Leukemia: A Double-Blind Randomized Clinical Trial. Iranian Journal of Pharmaceutical Research. 2016; 15 (2): 661-668

10. González-Gil1 EM, Santabárbara J, Russo P, Ahrens W., Claessens M, Lissner L, Börnhorst C, Krogh V, lacoviello L, Molnar D, Siani A, Tornaritis M, Veidebaum T, Moreno LA, Food intake \& inflammation in European children: the IDEFICS study. Eur J Nutr. 2016; 55:24592468

11. da Silva PM, Gauche C, Gonzaga LV, Costa ACO, Fett R. Honey: chemical composition, stability \& authenticity. Food Chem. 2016; 196:309-323.

12. Miguel MG, Antunes MD, Faleiro ML. Honey as a Complementary Medicine. Integrative Medicine Insights. 2017; 12: 1-15

13. Ajibola A. 2015. Physico-Chemical and Physiological Values of Honey and Its Importace as a Functional Food. International Journal of Food and Nutritional Science 2(2):180-188

14. Mofid B, Rezaeizadeh H, Termos A, Rakhsha A, Mafi AR, Taheripanah T, Ardakani MM, Taghavi SME, Moravveji SA, Kashi ASY. Effect Of Processed Honey And Royal Jelly On Cancer-Related Fatigue: A Double-Blind Randomized Clinic Trial. Electron Physician. 2016; 8(6): 2475-2482

15. Chayati I, Miladiyah I. Kajian Kadar Flavonoid, Aktivitas Antioksidan, Dan Kapasitas Antioksidan Madu Monoflora. MGMI. 2014; 6(1): 11-24

16. Saepudin R, Sutriyono, Saputra RO. Kualitas Madu yang Beredar Di Kota Bengkulu Berdasarkan Penilaian Konsumen dan Uji Secara Empirik. Jurnal Sain Peternakan Indonesia. 2014; 9(1): 30-40.

17. Kivrak S, Kivrak I, Karababa E. 2017. Characterization Of Turkish Honeys Regarding Of Physicochemical Properties And Their Adulteration Analysis. Food Science and Teknology, Campinas 37(1):80-89

18. Chakir A, Romane A, Marcazzan GL, Ferrazzi P. 2016. Physicochemical Properties of Some Honeys Produced from Different Plants in Morocco. Arabian Journal of Chemistry 9:S946S954
19. Salonen A, Tiitto J. Characterisation Of Two Unique Unifloral Honeys From The Boreal Coniferous Zone: Lingonberry And Mire Honeys. Agricultural and Food Science. 2012; 21: $159-170$

20. Ahmed S, Othman NH. Review of the Medicinal Effects of Tualang Honey and a Comparison with Manuka Honey. The Malaysian Jounal of Medical Sciences. 2013; 20(3): 6-13

21. Mohamed ZBH, Alfarisi HAH. Review Article Tualang Honey: Composition, Physiochemical Properties And Clinical Importance. Int. Res. J. Pharm. 2017; 8 (9): 1-5

22. Adalina Y. 2017. Kualitas Madu Puth Asal Provinsi Nusa Tenggara Barat. Prosiding Seminar Nasional Masyarakat BIODIV INDON 3(2): 189-193

23. Apriani D, Gusnedi, Darvina Y. 2013. Studi tentang Nilai Viskositas Madu Hutan dari Beberapa Daerah di Sumatera Barat untuk Mengetahui Kualitas Madu. Pillar of Physics 2: 91-98

24. Sjamsiah, Sikanna R, Rifkah AA, Saleh A. Penentuan Sifat Fisikokimia Madu Hutan (Apis dorsata) Sulawesi Selatan. Al-Kimia. 2018; 6(2): 185-193

25. Gairola A, Tiwari P, Tiwari JK. PhysicoChemical Properties Of Apis Cerana- Indica F. Honey From Uttarkashi District Of Uttarakhand, India. Journal of Global Biosciences Vol. 2(1), 2013, pp. 20-25

26. Cahyati I. Sifat Fisikokimia Madu Monoflora dari Daerah Istimewa Yogyakarta dan Jawa Tengah. AGRITECH. 2008; 28 (1): 9-14

27. Evahelda E, Pratama F, Malahayati N, Santoso B. Sifat Fisik dan Kimia Madu dari Nektar Pohon Karet di Kabupaten Bangka Tengah, Indonesia. AGRITECH. 2017; 37(4): 363-368

28. Nayik GA, Suhag $Y$, Majid I, Nanda V. Discrimination of high altitude Indian Honey by Chemometric Approach According to Their Antioxidant Properties and Macro Mineral. Journal of The Saudi Society of Agricultural Sciences. 2014; 17(2): 200-207

29. Susilo. Komposisi Madu. Jurnal Herbal Indonesia. 2004; 7(1) : 12-17

30. Olaitan PB, Adeleke OE, Ola IO. Honey: a reservoir for microorganisms and an inhibitory agent for microbes. African Health Sciences. 2007; 7 (3): 159-165

31. Alvarez-Suarez JM, Gasparrini M, ForbesHernández TY, Mazzoni L, Giampieri F. Review : The Composition and Biological Activity of Honey: A Focus on Manuka Honey. Foods. 2014; 3: 420-432. 